\title{
Industrial Property Rights Protection and Entrepreneurship Development in Nigeria: The Economic Implication
}

\author{
K.M. Waziri \\ Faculty of Law, University of Abuja, Nigeria \\ E-mail:kmwaziri2003@yahoo.com
}

Received: March 16, 2011

Accepted: April 20, 2011 Published: March 1, 2012

doi:10.5539/jpl.v5n1p93

URL: http://dx.doi.org/10.5539/jpl.v5n1p93

\begin{abstract}
The role of Industrial property in aiding the growth of entrepreneurship is enormous. The issues of SMEs to national economic growth, especially in developing economies in Nigeria cannot be overemphasised. One of the vital roles of entrepreneurship is accelerating the growth of SMEs. However, the entrepreneur is visible because of the development of Intellectual property and its protection. It is the hope and aspiration of every developing nation to achieve accelerated economic development. This can only be achieved through aggressive participation of the private sector and this role is assigned to the entrepreneur. But does this economic burden rest solely on the entrepreneur's shoulders? It is this pertinent issue that would be looked at in this paper amongst others.
\end{abstract}

Keywords: Industrial property protection, Entrepreneurship development, Economic implications

\section{Introduction}

The right to property underscores economic exchange and trade. This is true because no one can rightly give what he does not own. Thus, the right of ownership on any property justifies whatever actions that the economic agent who owns such property takes concerning it. He may want to trade on it, give it out as gift or even throw it away. Whatever choice he makes regarding the property is rightly his. Tied to this notion is the exclusivity right that is, the right which the property owner has to exclude others from the use of the property. By implication and extension, therefore, modern economies derive its force essentially from the rights which its various actors have over their possessions and which they voluntarily offer in exchange for other goods and services which given their human and resource limitations they cannot produce by themselves (Note 1).

Hardly is there any property anywhere in the world without some claims to its ownership. Therefore, there exist variants of rights such as government property rights where government is the exclusive owner, public (or commonly owned) property rights and private property rights where individual members are the owners. One of our concerns here is to examine the state of private property rights in Nigeria and the extent to which it either supports or hinders our growth and development.

The industrial revolution of the late 1780 s in Europe and early $19^{\text {th }}$ Century in America influenced significantly work ethics, organizational behaviour, thinking and management of productive resources (land, labour, capital and enterprise). Thus, the phenomenal growth of the economy is attributable to enterprising management of resources where entrepreneurship factor is a very important factor of production that co-ordinates the sometime idle factors of production such as land, labour and capital. However, a determinant for growth of the economy has gone beyond "labour, capital, and enterprise". Indeed, it is determined by infrastructure- which is derived from super-infrastructure called Intellectual Property from which Industrial Property arise. The ability of the mind to conceive, produce, and market are the true variants for economic growth.

\section{Entrepreneurship in Nigeria}

Entrepreneurship started when people produced more products than they needed; as such, they had to exchange these surpluses. For instance, if a blacksmith produced more hoes than he needed, he exchanges the surplus he had with what he had not but needed; maybe he needed some yams or goat, he would look for someone who needs his products to exchange with. By this way, producers came to realize that they can concentrate in their areas of production to produce more and then exchange with what they needed.

So, through this exchange of products, entrepreneurship started. A typical Nigerian entrepreneur is a self made man (Note 2) who might be said to have strong will to succeed. He might engage the services of others like friends, 
mates, in-laws among others to help him in his work or production. Through this way, Nigerians in the olden days were engaged in entrepreneurship. Early entrepreneurship is characterized with production or manufacturing; the producer most often started with a small capital, most of it from his own savings. Early entrepreneurship started with trade by barter even before the advent of any form of money.

Modern entrepreneurship in Nigeria started with the coming of the colonial masters who brought in their wears and made Nigerians their middle men. In this way, modern entrepreneurship was conceived. Most of the modern entrepreneurs were engaged in retail trade or sole proprietorship (Note 3).

Such economic policy programs that are geared towards self-reliance for individuals are programs as Open Apprenticeship Scheme, Graduate Employment Programs et cetera and other policies that encourage or make it easy for entrepreneurs to acquire the needed funds for example, Peoples Bank of Nigeria, Funds for Small-Scale Industries (FUSSI), co-operative societies etc were established to assist entrepreneurs in Nigeria.

According to Say in 1803, as cited by Hisrich and Peters (Note 4), an entrepreneur is someone who consciously moves economic resources from area of low yield to area of high yield. He redeploys people, material, money and co-ordinates the processes necessary for efficient large scale industrial/trade development. Joseph Schumpeter (Note 5) added that the entrepreneur is the motive behind capitalist development. Entrepreneurship spirit pervades all economies (though more with free market or capitalist economies) and is considered the bedrock of modern economic development through innovation, technological breakthrough and by developing untried technologies.

The entrepreneur in his entrepreneurial activities can bring about increase in production, create employment, income, facilitates rapid growth of micro, small, medium and large scale enterprises to reduce poverty and hunger among the people. Given this background, it is imperative to explore the extent to which entrepreneurship contributes to innovation and growth of enterprises/industries in Nigeria.

\section{Concept of Entrepreneurship}

Literature abounds as to what entrepreneurship is all about. Davis in 1983, as cited in Igbo (Note 6), sees entrepreneurship as the creation and running of one's own business. Timmons in 1987, also cited in Igbo (Note 7), sees it as the creation, building and distribution of something of value from practically nothing to individuals, groups, organizations and society. He summed up by stating that it involves planning and organizing small business ventures through the mobilization of people and resources to meet people's needs.

According to Schumpeter (Note 8), entrepreneurship is a process of change where innovation is the most vital function of the entrepreneur. It is the basic requirement for economic development in a free enterprise or mixed economy where innovation is the basis of development. Innovation in a system can increase the marginal productivity of the factors of production.

The United Nations Industrial Development Organisation (UNIDO) (Note 9) defined entrepreneurship as the process of using initiative to transform business concept to new venture, diversify existing venture or enterprise to high growing venture potentials.

The foregoing definitions and discussions point to the fact that entrepreneurship involves innovation, development, recognition, seizing opportunities and converting opportunities to marketable ideas, value while bearing the risk of competition.

Entrepreneurial development is a catalyst for economic, social and industrial development. Peter and Clark in 1997, as cited in Egai (Note 10), affirms that entrepreneurial development is a disposition to accept new ideas, new methods and making people more interested in present and future than the past.

The entrepreneurial class provides leadership in resource change, innovation, technical progress and capital formation to produce new knowledge, new production techniques/possibilities, profits and economic growth. Historically, entrepreneurship development in Nigeria has remained excluded from industrial policy until changes began to occur in 1980s due to ambivalency of competition and increasing service sector.

According to Audretsch and Thurik (Note 11), the role of the entrepreneurial sector changed when industrial comparative advantages shifted towards knowledge-based economic activities. Large firms lost their competitive edge while smaller and more flexible entrepreneurial firms gained new importance in the increasing knowledge-based economy. New dynamic ventures are acknowledged to be drivers of innovation.

Associated with entrepreneurship is the concept of intrapreneurship (Note 12). This involves entrepreneurship ingenuity and spirit within an organization rather than outside. It provides opportunities to hard-to-find key employees of an organization to unfold their potentials, performance and hard work to earn a reward or share in the profit or revenue generated by his ingenuity for the enterprise. The concept of intrapreneurship is beginning to spread rapidly in 
modern times.

The actor at the centre of entrepreneurship is the entrepreneur who possesses the following characteristics and traits.

\subsection{Personal Attributes and Traits}

An entrepreneur should be hard working, self discipline, confident, determined, innovative, visionary, risk-taker, consistent, independent, lead, amenable to change or flexible. All these traits prepares him against the odds to success.

\subsection{Creative Attributes or Technical Skills}

The entrepreneur requires unique skills such as prowess in communication, writing, engineering technology, environmental management monitoring, interpersonal relation, building, Networking, coaching, organizing, art making, technical drawing etc (Note 13).

\subsection{Business Management Skills}

These are specific skills for decision making such as accounting/finance, managerial, marketing/sales, information and operational/logistics skills. The entrepreneur should be able to keep proper accounting records, financial/investment details, promote sales, communicate effectively to give clear instructions and direction and build good feasibility studies. He should be able to exploit the Strengths, Weaknesses, Opportunities and Threats (SWOT) in his environment for survival of competition (Note 14).

\section{Meaning of Industrial Property}

The definition of the term "industrial property" has been subjected to numerous constructions by just as many authors and writers in this field and certain conventions have come out with their own description of this term. This work will not qualify as complete without a degree of attention (however slight) paid to these definitions. According to the Paris Convention for the protection of Industrial Property: "Industrial property shall be understood in the broadest sense and shall apply not only to industry and commerce proper, but likewise to agricultural and extractive industries and to all manufactured or natural products. For example; wines, grain, tobacco leaf, cattle, minerals, mineral water, beef, flowers and flour" (Note 15).

Industrial property typically consists of signs transmitting information to consumers, in particular as regards products and services offered on the market, and that the protection is directed against unauthorized use of such signs which is likely to mislead consumers and misleading practices in general (Note 16).

Industrial property takes a range of forms, the main types of which includes:

i. Patents to protect inventions; and industrial designs, which are aesthetic creations determining the appearance of industrial product; and

ii. Trademarks, service marks, layout-designs of integrated circuits, commercial names and designations, as well as geographical indications, and protection against unfair competition (Note 17).

\section{Role of Government in Entrepreneurship Development in Nigeria}

Economic growth rates are often attributed to the role of the duo of government and entrepreneurs which is complementary and not mutually exclusive (Note 18). The role of government in entrepreneurship development in Nigeria became significant only after the Nigeria civil war (1967-70).

Since the mid 1980s, there has been increased commitment of government to entrepreneurship development especially after the introduction of the Structural Adjustment Program (SAP) in 1986. Added to this, is the establishment of the National Directorate of Employment (NDE), National Open Apprenticeship Scheme (NOAS), Small and Medium Enterprise Development Association of Nigeria (SMEDAN), SMEEIS et cetera.

Fundamentally, Nigerian government promotes entrepreneurial culture through initiatives that builds business confidence, positive attitude, pride in success, support and encouragement of new ideas, social responsibility, providing technological supports, encouraging inter-firm linkages and promotion of Research \& Development. Others are cheap financial resources, free access to market, prompt registration/advisory service to businesses, promotion of entrepreneurial skills acquisition through education and manpower development, production of infrastructure, export incentives, stable macroeconomic environment, security of investment, stable political climate et cetera.

In early 2000s, entrepreneurship studies have been introduced into the Nigerian educational system especially higher institutions as a mandatory course. The Centre for Entrepreneurship Development (CED), which has the objective of teaching and gingering students of higher institutions (especially in science, engineering and technological (SET)) to acquire entrepreneurial, innovative, and management skills, was established. This is to make the graduates self-employed, create job opportunities for others and generates wealth. But one should be quick to add that all these 
efforts have not yielded any positive result because government is not indeed giving positive leadership to this end. E.g. there is no power, no infrastructures like roads, accommodation, e.t.c. and no credit facilities from banks to aid this sector.

UNESCO (Note 19) Programmes in Nigeria are aimed at fostering linkage and cooperation between higher institutions and industries such that academic research findings can readily be taken up by industries for production and product development.

\section{The Entrepreneur in Innovation and Economic Development}

According to Schumpeter (Note 20), capital and output growth in an economy depends significantly on the entrepreneur. The quality of performance of the entrepreneur determines whether capital would grow rapidly or slowly and whether the growth involves innovation where new products and production techniques are developed. The difference in economic growth rates of countries of the world is largely due to the quality of entrepreneurs in the countries. Production factors of land, labour and capital are said to be dormant or indolent without the entrepreneur who organize them for productive ventures.

The entrepreneur is, therefore, an important agent of growth of innovations and technical progress. The development and utilization of his technical and commercial skills create growth potentials in Micro, Small and Medium scale enterprises.

The present day economy is knowledge-driven operating on the pragmatic and innovative thoughts of the entrepreneur. Business set ups have become informal and oriented towards survival and self employment. Technical progress essentially results in increase in production, employment of labour, stimulation of export and overall growth of GDP. The contribution of entrepreneurship to the growth and development of Asian countries (China, Malaysia and Singapore) and African countries (South Africa and Nigeria) cannot be over emphasized.

In Nigeria entrepreneurship development and innovations have been manifested in all aspects of the economy viz; micro business, micro finance, small, medium industries, cottages, crafts, information/telecom services, personal services in food vending/restaurant, garments making, embroidering, agricultural produce, music, film production etc.

\section{Entreppreneurship Development and Growth of Enterprises and Industrial Organisations in Nigeria}

As earlier mentioned, entrepreneurship development in Nigeria became significant only after the Nigerian civil war. At the end of the war the second National Development Plan in place focused on the development of the 3Rs objectives of Reconstruction, Re-development and Reconciliation with all Nigerians. The activities in the plan challenged/task the ingenuity and inventive skills of the individuals. Added to this was the promulgation of the Nigerian Enterprise Promotion Decree of 1972 as amended in 1977 as indigenisation decree. This action further act as a catalyst to entrepreneurship business development as businesses hitter-to monopolized and reserved for the colonial entrepreneurs by the Royal Niger Charter were returned and reserve solely for the Nigerian entrepreneurs.

This early period of history witnessed economic development ideology of industrialization as the ultimate source of economic growth and industrialization. Technical progress or capital growth on the other hand is seen to be a function and the result of entrepreneurship effort. In particular evidence from the developed world according to Joseph Schumpeter (Note 21) indicates that economic growth is entirely due to the quality and efficiency of the entrepreneur. Thus after independence in 1960 there was the need by government to promote indigenous entrepreneurs who were hitherto displaced and outlawed by the British Royal Niger company. The Government never loses sight of the tripartite relationship between Entrepreneurship, Industrialisation and Economic growth order of influence. Thus the key or source or agent of economic growth is the entrepreneur who has to be developed and supported by government to effectively play this role.

Amendment of the indigenization decree in 1987 and the introduction of privatization and commercialization decrees in 1988, 1989 and 1995 further boosted the development of indigenous entrepreneurship. Individual and group interest/awareness was aroused leading to venturing in mining, banking, knowledge industry, education, publishing, information technology et cetera. As mentioned earlier there are some governmental policies and activities which spurred entrepreneurship development.

\section{The Economic Implication}

It is obvious that entrepreneurship is the engine of economic development. However, entrepreneurship will remain at the level of Small and Medium -scale enterprises and never metamorphose into large-scale industries if there is no guarantee for the protection of industrial property. Entrepreneurs will only invest their energy, resources and creative ability if they are sure that they will not be robbed of the fruits of their labour. 
Accordingly, if people have rights over their output, the additional incentive to produce more will enable the larger society to benefit. For instance, although the owner/entrepreneur appropriates his profit, there may be opportunities for people to work in such enterprise and earn wage income; hitherto non-existent services or goods can be introduced; healthy competition which can lead to better product quality as well as competitive prices will take place. What it means is that a well protected system of property rights stimulates economic productivity (Note 22).

Industrial property rights' protection directly increases the earning capacity of the creator or originator of the protected item. With his creations (designs, industrial designs and trademarks) receiving adequate protection, the originator has additional incentive to be creative. He also has enough finances to go corporate and employ more. In ensuring the continuity of his work, he increases the society's employment rate and boosts the economy (Note 23).

\section{Observations}

The growth of entrepreneurship and economic development is hampered in Nigeria due to the following reasons:

i. Lack of basic infrastructure amongst which is energy

You can not talk about entrepreneurship in any given environment without energy because it is the bed rock or the engine that pushes entrepreneurship growth in any economy. Not to talk of roads and other social amenities needed to further the development of this area in discuss.

\section{ii. Lack of funds}

The banking system in Nigeria can not be opened to entrepreneurs while in the other hand the micro-finance banks can not meet the demands of the entrepreneurs. As such, funding to actualise their objectives has become basically non-existent.

iii. Insecurity

The high rate of insecurity in the country is grossly hampering the flow of Foreign Direct Investment (FDI) and in effect affecting entrepreneurship development because without foreign capital, foreign know-how and positive business partnership, entrepreneurship can never develop.

iv. Inconsistency and lack of planning in government economic policies.

v. Endemic and Institutionalized corruption.

vi. A decayed educational system.

vii. Government lack of interest, knowledge and understanding of Intellectual Property as an engine of economic growth.

\section{Conclusion}

Going from the foregoing discourse, it is evident to say that the role of an entrepreneur in the development of the economy of a nation especially a nation like ours (which has good population, favourable weather, and abundant natural resources) can not be over-emphasized. Entrepreneurship development and innovations in Nigeria is at the peak of its awareness, creation and participation by both the people and government. Policies of government have shifted to addressing the problems of infrastructural decay and finance. The problem of power supply is still very much on ground while credit framework via microfinance banks put in place to assist entrepreneurs with soft loans is still at its infancy. However, Nigerian entrepreneurs still face doldrums of problems and challenges in their struggle for innovation and technical progress.

The ability of government to protect property rights theft and violations and the will to achieve same will be the underlining factor for economic growth and indeed entrepreneurship development.

\section{Recommendations}

1. It is like there is no government in Nigeria when it comes to planning and implementing economic Policies. There must be strong institutions, based on planning and information to implement key economic policies to stimulate growth and development of the economy.

2. The banks are in fact not providing the desired services to encourage entrepreneurship. Small business cannot acquire loans from our banks; they are in fact not accessible by certain categories of businesses e.t.c. Our banks should be categorised to give room for SMEs to access soft loans to boast their trades.

3. There is total lack of infrastructure which is the basic stimulants to economic growth and entrepreneurship. There is no energy in Nigeria, no linkage roads and the major roads are mostly bad. There is no transport policy; all these defects fall back to the entrepreneur. No one needs to tell us that it can not develop in this part of the 
world. It is therefore our understanding that basic infrastructures like energy, roads, and transport must be accorded priority attention in order to accelerate the growth of SMEs and Entrepreneurship.

4. There is substantial decline in our educational system at all levels. This is a major set back to almost all our laudable programmes. No research to encourage and espouse our developmental desires. Our higher institutions and research institutions must as a matter of urgency be well funded to give quality education and undertake researches to serve as stimulants to the growth of the economy.

5. Government dependence on oil revenues has remained a major resource course. Government has no interest or lack the knowledge of intellectual property as an engine of economic growth and industrialization. Government should provide a strong agency to coordinate all the component part of intellectual property and make it part of Government policies in MDAs and parastatas that are directly link to intellectual property.

6. Government policies no matter how laudable are destroyed by endemic corruption. There is in Nigeria both visible and invisible corruption. There should therefore be a concerted effort to fight corruption to a stand still by Government(s).

7. There is alarming cases of insecurity in the country, and the prevalence of insecurity drives away Foreign Direct Investment (FDI) and in effect affects directly the growth and development of the SMEs and entrepreneurship.

\section{References}

Audretsch \& Thurik. "Role of government policy on entrepreneurial activities" [Online] Available: http://en.wikipedia.org/wiki/entreprenurship (May 11, 2009)

Egai N. A. "Entrepreneurial development for increased Competitiveness and Business growth". Institute of Chartered Economists of Nigeria's Seminar" Abuja: National Centre for Women Development. $6^{\text {th }}$ June 2008.

Eshiobo. S.S. Entrepreneurship in Innovation, Phenomena Growth of Enterprises and Industrial Organisations in Nigeria

Igbo C. "Modern Institutional Techniques and their Application in Technical Vocational Education Programs of Polytechnic and Monotechnics". ETF Capacity Building Workshop, Auchi Nigeria, Nov 2005.

Martin Oluba. "Property Rights in Nigeria and the Challenge of Economic Development, Economic Reflections" Vol. B. No. 1, (2008) P.2.

McOlive .T.O, Okafor .F.C, Nwagwu .N.A \& Okojie .C.E.E. (2006). "Entrepreneurship Development: The Nigerian Experience", March Publishers Benin

Schumpeter J. (1975). Theory of Economic Development. Cambridge:Howard University Press. WIPO . WIPO Intellectual Property Handbook: Policy, Law and Use, WIPO Publication (2004)

WIPO Publication, Understanding intellectual property, WIPO Publication CBN: Statistical Bulletin, (2006).

\section{Notes}

Note 1. Martin Oluba, Property Rights in Nigeria and the Challenge of Economic Development, Economic Reflections" (2008): http://www.martinoluba.com/publications/articles/Property\%20Rights.pdf.

Note 2. Nicks., The History of Entrepreneurship in Nigeria. http://bizcovering.com/history/the-history-of-entrepreneurship-in-nigeria/

Note 3. Ibid.

Note 4. Hisrich R. D \& Peter M. P. Entrepreneurship. Singapore: McGraw-Hill. (2002),

Note 5. Schumpeter J., Theory of economic Development. Cambridge: Howard University Press, (1975), p. 7-8

Note 6. Igbo C. "Modern institutional techniques and their application in Technical Vocational Education Programs of Polytechnic and Monotechnics". ETF capacity Building Workshop, Auchi, Nov., (2005), Quoted in Eshiobo S.S., Entrepreneurship in Innovation, Phenomena Growth of Enterprises and Industrial Organisations in Nigeria

Note 7. Ibid.

Note 8. Schumpeter J., Op.cit. p. .8.

Note 9. UNIDO Report 1999. Retrieved from http://www.unido.org.

Note 10. Egai N. A., "Entrepreneurial development: for increased competitiveness and Business growth'. Institute of Chartered Economists of Nigeria's Seminar". Abuja: National Centre for Women Development. $6^{\text {th }}$ June (2008), Quoted in Eshiobo S.S., Entrepreneurship in Innovation, Phenomena Growth of Enterprises and Industrial 
Organisations in Nigeria.

Note 11. Audretsch \& Thurik,. "Role of government policy on entrepreneurial activities" Retrieved from http://en.wikipedia.org/wiki/entreprenurship 2001on May 11, (2009).

Note 12. Eshiobo. S. S, Entrepreneurship in Innovation, Phenomena Growth of Enterprises and Industrial Organisations in Nigeria. P.2

Note 13. McOlive .T.O, et al.. (eds.) Entrepreneurship Development: The Nigerian Experience, (2006)

Note 14. Eshiobo. S. S op. cit. p.11.

Note 15. Article 1(3) of the Paris Convention for the Protection of Industrial Property 1883.

Note 16. WIPO, WIPO Intellectual Property Handbook: Policy, Law and Use, WIPO Publication (2004).

Note 17. World Intellectual Property Organization Publication, Understanding intellectual property, WIPO Publication. P. 4-5.

Note 18. It is the role of government to develop transportation, power, financial inducement, subsidies and other utilities to encourage entrepreneurship development. Furthermore, government is expected provide security to safe guard life and property; maintaining law and order and freedom to do business but is yet to be achieved in Nigeria.

Note 19. United Nations Educational Scientific and Cultural Organisation.

Note 20. Schumpeter J. Op.cit p. 8.

Note 21. Ibid

Note 22. Martin Oluba, "Property Rights in Nigeria and the Challenge of Economic Development, Economic Reflections". Vol. B. No. 1, (2008) p.2.

Note 23. Brazil's unemployment rate has drastically reduced to as low as $13 \%$ with the advent of entrepreneurship development and industrial property protection. 